East African Journal of Science, Technology and Innovation, Vol. 2 (1): December 2020.

This article is licensed under a Creative Commons license, Attribution 4.0 International (CC BY 4.0)

\title{
Effects of agricultural intensification practices on smallholder farmers' livelihood outcomes in Kenyan hotspots of Climate Change
}

\author{
$1,2{ }^{*}$ OUYA, F. O., ${ }^{1}$ AYUYA, O. I., 1 KARIUKI, M. I
}

\author{
${ }^{1}$ Department of Agricultural Economics and Agribusiness Management, Egerton University P. O. Box 536 - 20115, Egerton. \\ 2 Push-pull department, International Centre for Insect Physiology and Ecology (ICIPE) P. O. Box 30 - 40305, Mbita. \\ *Corresponding author: fredrickouya@gmail.com
}

\begin{abstract}
Developing countries, Kenya included are mostly affected by food shortage and poverty as a result of high dependence on agriculture constrained by climate variability, declining land sizes and low agricultural technologies. Agricultural intensification is key in solving these problems to ensure increased farm output per unit land area. This study analyzed the role of agricultural intensification on smallholders' poverty and food security status. The study is based on data collected from a sample of 320 smallholder households from two Sub-counties of Kenya, Makueni and Nyando. Principle Component Analysis (PCA) was first used to group agricultural intensification practices into clusters. The Multivariate Tobit results indicated that age of the household head, household size, and proportion of land cultivated, number of trainings, group diversity, location and level of agricultural intensification significantly influenced households' food security status during the food secured and food insecure months as well as their poverty status. The study recommended on the need for smallholder farmers to form and join many groups which promote social networks thus reduce information asymmetry and improves their bargaining and borrowing power. It also suggested on the need for policy geared towards training and extension which is generation specific that can easily be incorporated by both the old and the young farmers. Through these, there will be increase in the level of agricultural intensification used by smallholder farmers which successfully will lead to improvement of food security and reduction of poverty.
\end{abstract}

Keywords: Food security; Climate change; Poverty; Kenya.

\section{Introduction}

Eradication of poverty and extreme hunger are among the sustainable development goals the world has to overcome (FAO, 2015). Extreme hunger can be solved through increased agricultural production. Around 41 percent of the land on Earth is occupied by dry land and it is a home to half of the people living in poverty (Kok et al., 2016). However, it is clear that climate change is a looming challenge to the eradication of global poverty and hunger, which calls for urgent action (GoK, 2017). The extreme climate condition leads to low agricultural production forcing vulnerable farmers living in dry regions to exploit
Cite as: Ouya et al., 2020 Effects of agricultural intensification practices on smallholder farmers' livelihood outcomes in Kenyan hotspots of Climate Change. East African Journal of Science, Technology and Innovation 2(1)
Received: 20/11/19

Accepted: $06 / 11 / 20$

Published: $11 / 12 / 20$ 
the available natural resources causing more damage to the environment further hindering their growth and development.

Worldwide, developing countries are the most affected by food problems and poverty as a result of their high dependency on agriculture. Radical change in agricultural and food systems is therefore paramount to enhancing the contribution of the sector to alleviation of poverty and extreme hunger (Dobermann et al., 2013). However, agricultural production in developing regions in the world is dominated by smallholder agriculture whose contribution to future food production is hampered by climate variability, declining land sizes, low use of agricultural technologies and weak policies (Mugi-ngenga et al., 2016; Oluwatayo and Ojo, 2016). These challenges result in low agricultural productivity which, in turn, translates into food-related problems and poverty. One way of addressing these challenges of the declining land sizes and climate change requires uptake of agricultural intensification practices by smallholder farmers (Vermeulen et al., 2011; Leigh et al., 2014).

Agricultural intensification involves increasing capital or labour average inputs on a cultivated land and the grazing land purposely in order to increase output value per acre (Tiffen, 2006; Vermeulen et al., 2012) or increasing production per animal and per labour unit. Furthermore, agricultural intensification involves the use of soil and water conservation practices. As farm sizes became smaller and smaller due to population increase and land was continuously being disintegrated among family members, steep plots which were previously left fallow were cultivated. According to Abukari (2014), increasing agricultural production in the face of climate change calls for smallholder farmers intensifying their agricultural production systems. Thus, agricultural intensification has to be pursued as a livelihood strategy for gaining more from agriculture by investing more capital or labour per unit area.

Majority of smallholder farmers in Makueni and Nyando sub-counties in Kenya are poor and highly depend on agriculture as their primary source of livelihood. The two sub-counties are semi-arid and regarded by Climate Change and
Food Security (CCAFS) as hotspots of climate change (Silvia et al., 2015). Most farmers in these regions rely on open field, unreliable rain-fed agriculture. Both sub-counties have an estimated poverty rate of 60 percent (GoK, 2013a, 2013b). In spite of challenges facing smallholder farmers, the government and private partners promoted and encouraged uptake of agricultural intensification practices in the regions. For instance, these organizations have promoted the uptake of organic and inorganic fertilizers, drought resistant crop varieties, improved indigenous chicken among others. Besides these, there has been promotion of training and capacity building at farm levels. The organizations also encourage formation of local institutions in order to assist in agricultural intensification.

There has been an increasing recognition of the role of agricultural intensification in improving livelihoods of rural smallholder farmers (Amekawa et al., 2010: Ickowitz et al., 2019). Agricultural intensification puts less pressure on natural resources, increasing agricultural productivity, building smallholder resilience to climate changes and improvement of their livelihoods (Chartres et al., 2015: Tscharntke et al., 2012: West, 2009: Woelcke, 2006). However, in the dry regions, the effect of agricultural intensification on food security and poverty has been unclear in empirical literature. Furthermore, much focus of agricultural intensification is on ensuring higher yields on the same piece of land, ignoring its links to rural livelihoods. Therefore, it was against this background that the current study aimed at filling these knowledge gaps. This study is aimed at informing policy makers and development partners including CCAFS, in the contribution and designing of strategies, when supported will enable smallholder farmers access necessary resources for agricultural intensification, leading to food security, increased output, reduced vulnerability, improved income and their wellbeing.

This study is the first to use Household Food Security Consumption Score (HFCS) for the good and the bad months of the year to account for the seasonal variation of food security. This has been a limitation in the case of using Household Dietary Diversity Score (HDDS) and Household 
Food Insecurity Access Scale (HFIAS) (Issahaku and Abdulai, 2019). As argued by Bayene (2014), smallholder farmers engage in crop production during rainy season, so rural household food security varies depending on the season of the year. Secondly, this study is believed to be among the few if not the first to consider smallholder farmers' food security and poverty in all agricultural enterprises they practice. In dry areas, farm diversification is the order of the day as the farmer may fail to harvest one or more crop but succeed in other farm enterprises. Crop diversity is an important factor in increasing food security as it result in more diversified human diets and it can increase yield stability, it is a smallholder potential strategy for mitigating food security in SSA (Silvia et al., 2015). Because farmers in the two regions practice mixed farming this study accommodates practices both in livestock and crop enterprises as they practice them interdependently.

\section{Materials and Methods}

\section{Study Area}

This study was based on data collected in September and December, 2016 in Makueni Subcounty in the Eastern Region and in Nyando Subcounty in the Nyanza Region respectively. These sites were selected by Climate Change, Agriculture and Food Security (CCAFS) research program using poverty levels, vulnerability to climate change, agricultural production systems, climatic and agro-ecological gradients. These sites were hot spots of climate change and food security and Makueni (Wote) was the driest site (Silvia et al., 2015). The large part of the subcounty is mostly arid and semi-arid and prone to frequent droughts. The lower side which is very dry receives little rainfall ranging from $300 \mathrm{~mm}$ to $400 \mathrm{~mm}$ but some parts can receive annual rainfall as high as $800 \mathrm{~mm}$ (GoK, 2013a). The rainfall pattern is bimodal with long rain season on March/April and short rain season which is their 'main season' occurring on November/December. The Sub-county has experience climate change of unreliable rainfall due to human activities like farming, charcoal burning, and sand harvesting (GoK, 2013a).
Nyando Sub-county temperatures range between $22^{\circ} \mathrm{C}$ to over $37^{\circ} \mathrm{C}$. The altitude ranges from $1100 \mathrm{~m}$ above sea level along the Kano plains to $1500 \mathrm{~m}$ above sea level around the Kericho and Muhoroni border. Nyando experiences bimodal rainfall with the long rains received from March to June and the short rains coming from September to November. The mean annual rainfall ranges between $600 \mathrm{~mm}$ to $1,700 \mathrm{~mm}$ (GoK, 2013b).

\section{Sampling procedure}

This study was conducted in a resample of the farm households that were previously surveyed by CCAFS research program (https://ccafs.cgiar.org/) in 2012. A $100 \mathrm{Km}^{2}$ (10 $\mathrm{km}$ by $10 \mathrm{~km}$ ) research grid was picked on each selected site of Nyando and Makueni Subcounties. Secondary data were gathered by CCAFS research project which acquired high resolution satellite images, generated maps, and geo-referenced lists of all villages within each research grid. On each research grid, the agreed sample of 16 villages was selected. Villages in build-up areas (urban or peri-urban) were excluded from the lists. Household lists were collected from the sampled villages by village elders/managers who knew the boundaries and verification of the lists were conducted by CCAFS officers through door to door confirmation, numbering them and additional households were found in some villages (Rufino et al., 2013). A total of 1600 households were in the source lists. The study used Yamane 1967, formula to sample households as follows;

$$
\begin{aligned}
S & =\frac{N}{1+N(e)^{2}} \\
S & =\frac{1600}{1+1600(0.05)^{2}} \\
S & =320
\end{aligned}
$$

This study sampled a total of 320 households that was ten respondents from each of the sampled 16 villages per site. With household lists from the sampled 16 villages in each grid in place, a systematic random sampling was used in every site and replacements done using the same method. Map of the study area is shown in figure 1. 


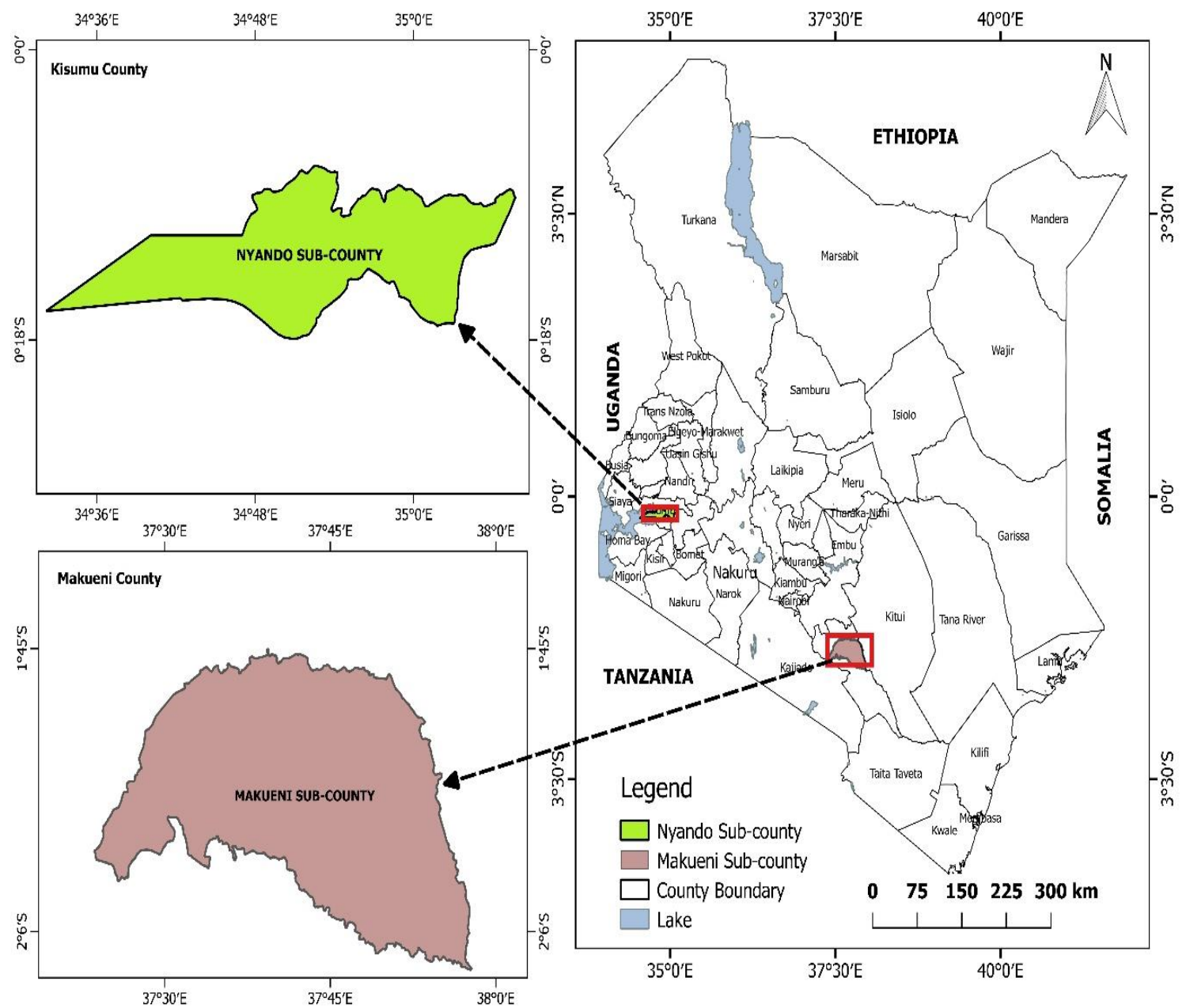

Figure 1: Map of study area

Source: Geography Department, Egerton University. 2017

\section{Data and Data collection}

This study was based on Rural Household MultiIndicator Survey (RHoMIS) data which was collected in the months of October, November and December, 2016. RHoMIS is a household survey tool designed to rapidly characterize a series of standardized indicators across the spectrum of agricultural production and market integration, nutrition, food security, poverty and greenhouse gas emissions. The exercise involved a team of well-trained enumerators with agricultural background and field experience, a team leader and a supervisor, data collection tool which was Open Data Kit (ODK) installed on android Tablets and other incidentals. A semi structured questionnaire was used.
A pretest was conducted in Makueni Sub-county and corrections or adjustments were made to the tool. Data was obtained through interviewing household heads or spouses. At the beginning of the exercise, a team leader conducted spot checks to identify common problems or poor skills this helped in evaluating and improving interviewer performance. A team leader also conducted back checks by asking few questions to cross check the authenticity of information collected, this was to ensure that the data collected was of high quality. Debriefing was conducted almost on a daily basis where challenges and concerns were raised and field experiences and ideas shared. Enumerators cleaned their data by the end of any data collection exercise, data backed up by the 
supervisor and sent directly from the tablet to a portal. The data was cleaned, organized and analyzed using STATA and SPSS computer software programs. The data collected included household and farm characteristics, crop productivity, livestock species and products, access to facilities, social capital, food security and progress out of poverty.

\section{Indicators of poverty and food security as used} in this study

Livelihood outcomes in this study were poverty and food security and these were measured using two indicators, Progress out of Poverty Index/Poverty Probability Index (PPI), and Household Food Consumption Score (HFCS). This objective looked at the smallholder farmers' poverty status and food security situation both in the good months and the bad months of the year which differs between the two sites. Good month is a period just after harvest where most foods are available to respondents in adequate quantity while bad month is a period of the year before harvesting and food is scarce to respondents. This objective therefore used Multivariate Tobit Model in determining the role of agricultural intensification on smallholder farmers' poverty status and food security both in the good month and the bad month of the year.

\section{Progress Out of Poverty Index/Poverty Probability Index (PPI)}

The study used PPI to measure the extent of poverty in the two selected sites of Wote/Makueni and Nyando Sub-counties. This study used the international US\$ 1.25 per day poverty line also specified in SDGs number one (Ravallion, 2013). The US\$ 1.25 which is the global common poverty measure which considers exchange rates and currency differences and is measured in economic unit called Purchasing Power Parity not in dollars (Grameen Foundation, 2018). It is used by international agencies, donors, many Nongovernmental organizations as well as microfinance institutions. PPI scores were added and the scores were from 0 to 100 . Zero (0) meant the household was most likely to be below the poverty line while 100 meant least likely below a poverty line/unlikely to be poor. Poverty likelihood score card in this study was used to estimate the probability that a particular household had a per-capita income below poverty line and it could also be used to estimate the poverty rate of a group of households at a point in time (Boka et al., 2017).

PPI scores were converted using look-up table to poverty likelihoods which is the probability that a household is below the poverty line. This was due to the fact that poverty is multidimensional. A household with a PPI score of 82, according to the look-up table for the PPI for Kenya, that household had a 0.1 percent likelihood or probability of living below the $\$ 1.25$ per day, meaning this household was well off and was probably living high above the poverty line. A household with a PPI score of 20 according to look-up table had 81.9 percent probability of living below the $\$ 1.25$ per day implying that the per capita income is far below the poverty line and are not in a position to afford the basic necessities of life (Desiere et al., 2015). PPI was censored from left 0 to right 100

\section{Household Food Consumption Score as a proxy for measuring Food Security}

The study used the adjusted Household Food Consumption Score (HFCS). The seven days recall of the World Food Program (WFP) was used for standardization and for comparison. The Food Consumption Score of the WFP applies dietary diversity of the food groups and the food frequency for number of days each food group was consumed within a week; this is according to Comprehensive Food Security and Vulnerability Analysis Guidelines (CFSVA). It is a fact that HFCS does not necessarily reflect the food security situation of the household as the CFSVA base its data collection on the current food security which is a short term classification, relying on the past seven days food consumption which might be influenced by seasonal factors, food aid among other factors (Headey and Ecker, 2013).

This study used different data collection method and analytical strategy which deviates from world food program (Kennedy et al., 2010; Headey and Ecker, 2013). Rural Household Multi Indicator Survey (RHOMIS) used dietary diversity of food groups and the same weighting system as used in WFP was maintained except 
asking how frequent these foodstuffs were consumed within a month or four weeks period in good season and in bad season (Hammond et al., 2015). The responses were in 'daily', 'weekly', 'monthly', or 'never'. This approach might give a lower accuracy than a seven-day recall but it takes consideration of seasonality of some food items to avoid biasness as well as to capture household food security at all times of the year allowing for seasonal variation. Appropriate locally consumed foodstuffs were chosen in each location (Silvia et al., 2015: Rufino et al., 2013). The calculation of HFCS in this study was made using a modification of WFP.

The frequency scores for 'daily' was 5, 'weekly' was 1.5 , 'monthly' was 0.25 while 'never' was 0 . Using these frequencies, the maximum HFCS for the good month had a value of 80 , also the bad month had a maximum value of 80 which could only be achieved if a household ate each food group every day for the last one month minimum in each case is 0 . The scores were censored from 0 to 80 . A lower score of zero means food insecure household while higher score of means food secure household.

HFCS calculations in this study followed the WFP instructions in most aspects but departed from the standard advice in terms of reference time period. The seven days recall period which can be very helpful in conducting Emergency Food Security Assessment. It can also be useful when the sites considered have the same characteristics like seasonality, and having the same harvesting period. But in a case where data is to be collected in a particular period for various sites almost at the same time like study Sites Makueni and Nyando Sub-Counties, generalization and restriction of HFCS to seven days recall is biased, this is what most researchers do (Kennedy et al., 2010).

The use of good and bad season or month is appropriate because households normally know their food consumption patterns (Hammond et al., 2015). HFCS is a qualitative measure of dietary and nutrient intake by the household which is less costly and less time consuming to collect (Kennedy et al., 2010).

\section{Analytical framework}

This objective was analyzed using Multivariate Tobit model. Multivariate Tobit model originated from Tobit model which was formulated by James Tobin (1958). Multivariate Tobit model was used to determine the role of agricultural intensification on livelihood outcomes such as Household food consumption score for the good month (HFCSGM), Household food consumption score for the bad month (HFCSBM) which were all used as a proxy for food security and Progress out of poverty index (PPI) which is a widely used standard indicator of poverty (Hammond et al., 2015).

Household food consumption score (HFCS) Tool is achieved as each food item is grouped and assigned weights. If a household ate each food group every day during the 7 days, then a maximum score for that household is 112 and if none is eaten then a minimum score is 0 . HFCS is important as it is related to health since it captures dietary quality and nutrient adequacy (WFP, 2008). PPI Tool uses 10 questions customized and translated for different countries; each answer is assigned a score. The sum of scores is taken to Lookup table. The Lookup table can be used to determine the probability that the household is below the poverty line.

Probit and logit models could be used but they assume that the dependent variable is a dummy which takes the value of 0 (no adoption) and 1 (full adoption). Estimation of the model using OLS was not appropriate as OLS produce both inconsistent and biased estimates, because OLS reduces the slope by underestimating the true effects of parameters (Gujarati, 2003). Therefore, the maximum likelihood estimation was recommended for Multivariate Tobit analysis. According to Ayuya (2018), Anastasopoulos et al., (2016) and $\mathrm{Xu}$ et al., (2014) the normal Tobit model (Tobin, 1958) is less appropriate approach while analyzing two or more dependent variables. Multivariate Tobit model was appropriately used in this objective because dependent variables were censored. The Multivariate Tobit model accounts for simultaneous equation error correlation among the livelihood outcomes proxies (HFCSGM, HFCSBM and PPI). 
The Multivariate Tobit model with three left-censored at zero dependent variables can be expressed as:

$$
\begin{array}{ll}
y_{i j}=x_{i j} \beta_{j}+\mathrm{u}_{\mathrm{ij}} & \text { if } \quad x_{i j} \beta_{j}+\mathrm{u}_{\mathrm{ij}}>0 \\
y_{i j}=0 & \text { if } \quad x_{i j} \beta_{j}+\mathrm{u}_{\mathrm{ij}} \leq 0, i=1,2 \ldots, \mathrm{N} \text { and } j=1,2,3 . .
\end{array}
$$

Multivariate Tobit model is best stated using latent equation as follows:

$$
\begin{aligned}
y_{i j}^{*} & =x_{i j} \beta_{j}+\mu_{\mathrm{ij}}, \ldots . . \\
y_{i j} & =y_{i j}^{*} \text { if } y_{i j}^{*}>0 \\
& =0 \text { if } y_{i j}^{*} \leq 0
\end{aligned}
$$

Where $y_{i j}^{*}$ is a latent variable for the $j^{\text {th }}$ livelihood outcomes intensity (1 through 3 for HFCSGM, HFCSBM, and PPI) for the $i^{\text {th }}$ household that is observed only when positive, meaning for values greater than 0 and censored for values less than or equal to 0 . The Multivariate Tobit model can be generalized to take account of censoring both from below and from above. $x_{i j}$ is a vector of independent variables which are level of agricultural intensification, socioeconomic and institutional characteristics of smallholder farmers. The $\beta_{j}$ is a parameter associated with the independent variables to be estimated. Where the error term $\mu_{\mathrm{ij}}$ is assumed to be distributed as normal distribution with zero mean and constant variance $\partial^{2}$ : as $\mu_{\mathrm{ij}} \sim \mathrm{N}(0$,

1) and $\mu_{\mathrm{ij}} \sim \mathrm{N}\left(0, \partial^{2}\right)$, correlation $(\rho)$.

The covariance matrix takes the form (Anastasopoulos et al., 2016):

$\Sigma_{\mu j}=\left(\begin{array}{ccc}\partial_{\mu_{1}}^{2} & \rho_{\mu_{2} \mu_{1}} \partial_{\mu_{2}} \partial_{\mu_{1}} & \rho_{\mu_{3} \mu_{1}} \partial_{\mu_{3}} \partial_{\mu_{1}} \\ \rho_{\mu_{1} \mu_{2}} \partial_{\mu_{1}} \partial_{\mu_{2}} & \partial_{\mu_{2}}^{2} & \rho_{\mu_{3} \mu_{2}} \partial_{\mu_{3}} \partial_{\mu_{2}} \\ \rho_{\mu_{1} \mu_{3}} \partial_{\mu_{1}} \partial_{\mu_{3,}} & \rho_{\mu_{2} \mu_{3},} \partial_{\mu_{2}} \partial_{\mu_{3}} & \partial_{\mu_{3}}^{2}\end{array}\right)$

Where $\mu j$ represent the error terms of HFCSGM, HFCSBM, and PPI respectively

The density function of $y_{i j}$ given the above error terms can be written as (Trivedi and Zimmer, 2005):

$$
f_{j}\left(y_{i j} \mid \beta_{j}^{\prime} x_{i j}\right)=\prod_{y_{i j}=0}\left[1-\Phi\left(\beta_{j} x_{i j}^{\prime} / \partial_{j}\right)\right] \prod_{y_{i j}>0} \varphi\left[y_{i j}-\Phi\left(\beta_{j} x_{i j}^{\prime} / \partial_{j}\right)\right]
$$

Where, $\Phi$ is the multivariate normal distribution function, and $\varphi$ is the multivariate normal density function. The corresponding log-likelihood function for the Multivariate Tobit model is:

$$
L_{L}\left[\left(y_{1} \mid x_{1} ; \beta_{1}\right),\left(y_{2} \mid x_{2} ; \beta_{2}\right),\left(y_{3} \mid x_{3} ; \beta_{3}\right), \omega\right]
$$$$
=\sum_{i=1}^{N} \sum_{j=1}^{3} \ln f_{i j}\left(y_{i j} \mid x_{i j} ; \beta_{j}\right)+\sum_{i=1}^{N} D_{123}\left[F_{1}\left(y_{i 1} \mid x_{i 1} ; \beta_{1}\right), \mathrm{F}_{2}\left(y_{i 2} \mid x_{i 2} ; \beta_{2}\right), \mathrm{F}_{3}\left(y_{i 3} \mid x_{i 3} ; \beta_{3}\right) ; \omega\right]
$$

Where, $\mathrm{D}_{123}($.$) is the cross partial derivative for the function linking marginal variables into the multivariate$ distribution (Trivedi and Zimmer, 2005; Prokhorov and Schmidt, 2009), $\omega$ is the parameter which measures the dependence between the marginal.

\section{Results}

From the data smallholder farmers in Makueni and Nyando Sub-Counties used 16 agricultural intensification practices in their farming systems (Table 1). Some of these intensification practices were correlated with one another and so
Principal Component Analysis (PCA) was used to reduce these intensification practices into smaller number of principle components. Principal Component Analysis helps in reducing data dimensionality without loss of much information. This study used Scree Plot test in choosing number of principle components, the 
aim of using PCA is to reduce the dataset and just using eigenvalues greater than or equal to one might give more components which are unreasonable. The Scree Plot test gave the five principal components (Figure 2). The intensity of agricultural intensification practice was therefore measured by the number of agricultural intensification components (practices) which was generated by the PCA. The results indicated that the number of components of users was ranging between 1 and 5 . That is from low users of strategy 1, partial users of 2, 3 and 4 to full users of 5 . The result revealed that 56.25 percent of farmers used 5 sets of practices while 30.63 percent, 8.44 percent, 3.44 percent and 1.25 percent of farmers used 4, 3, 2 and 1 levels of practices respectively as shown in Figure 3.

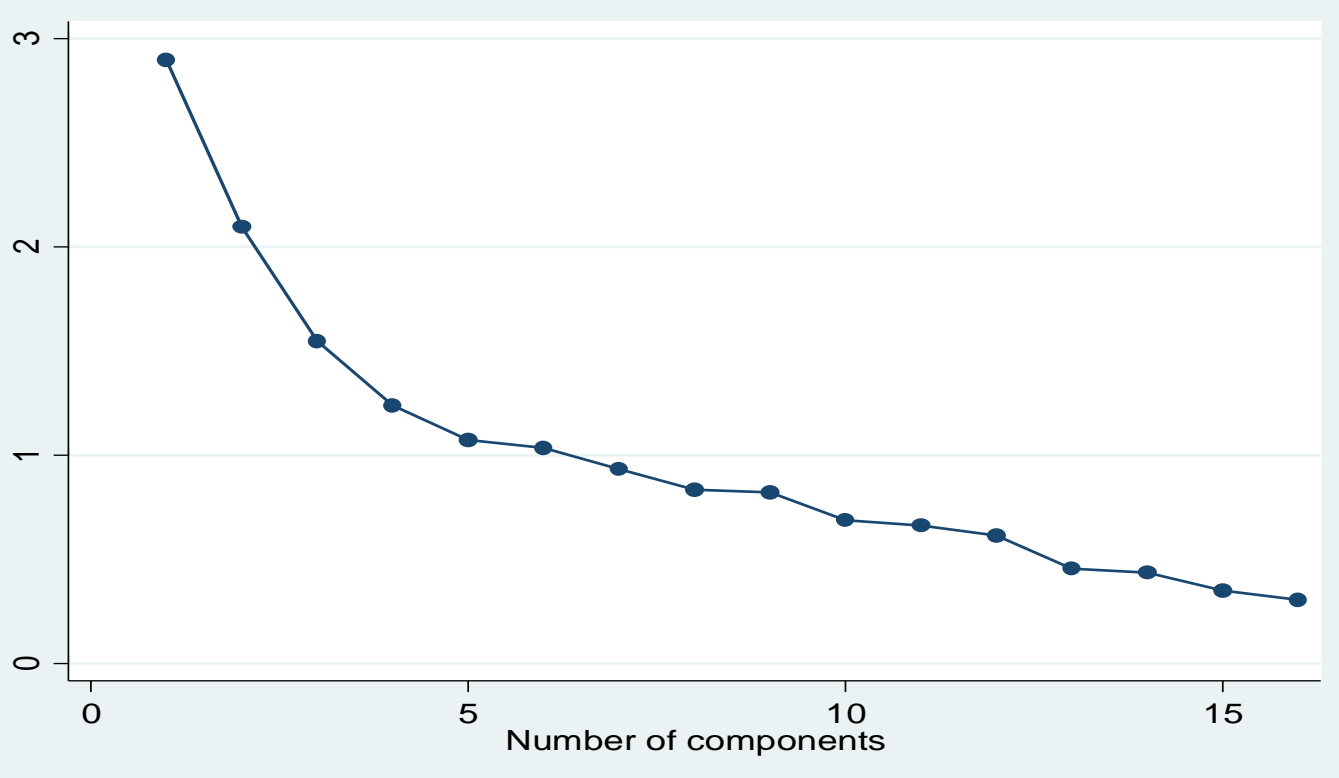

Figure 2: Scree plot of Eigenvalues

\section{\& Wote $⿴$ Nyando \$ Total}

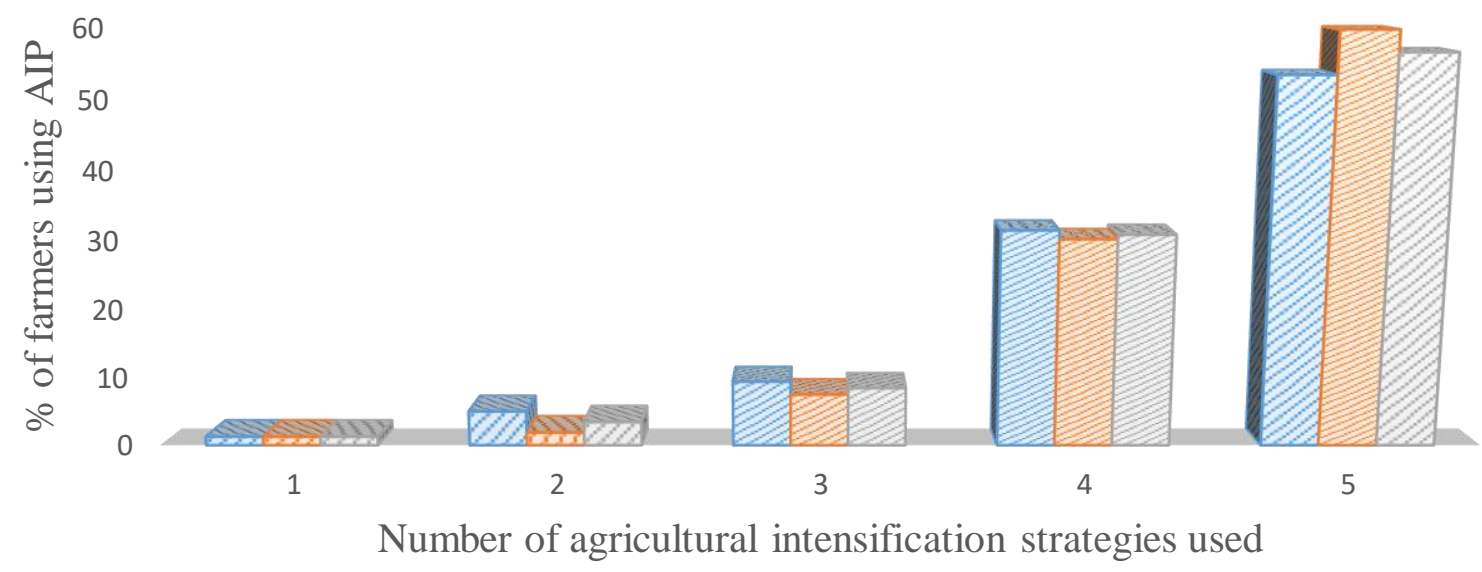


Figure 3: Farmers level of agricultural intensification practices (AIP) used

Agricultural technologies have diverse components which farmers could fail to practice, partially practice or fully embrace. This situation can be best handled by the Poisson regression or Negative binomial regression model. These count models have the capacity to estimate the effect of socioeconomic, farm and institutional characteristics on the level of agricultural intensification among smallholder farmers whether on the probability of one or multiple events as well as no events (Agula et al., 2018). Negative Binomial Regression was used to confirm whether there was over-dispersion but alpha test was not significant, hence Standard Poisson Regression Model was used. The intensity was modelled as the number of techniques/strategies practiced out of a maximum of five.

Table 1. Farmers' usage of agricultural intensification practices (Percentage of farmers)

\begin{tabular}{|c|c|c|c|c|}
\hline $\begin{array}{l}\text { Intensification } \\
\text { practice }\end{array}$ & Site & $\begin{array}{l}\% \text { of farmers } \\
\text { using practice }\end{array}$ & $\begin{array}{l}\% \text { of farmers not } \\
\text { using practice }\end{array}$ & Chi Square \\
\hline \multirow[t]{2}{*}{ Fertilizer } & Wote & 6 & 94 & 80.7768 *** \\
\hline & Nyando & 52 & 48 & \\
\hline \multirow[t]{2}{*}{ Manure } & Wote & 78 & 22 & $4.1278^{* *}$ \\
\hline & Nyando & 86 & 14 & \\
\hline \multirow[t]{2}{*}{ Compost } & Wote & 26 & 74 & $40.8631^{* * *}$ \\
\hline & Nyando & 2 & 98 & \\
\hline \multirow[t]{2}{*}{ Pesticides } & Wote & 61 & 39 & $34.1414^{* * *}$ \\
\hline & Nyando & 29 & 71 & \\
\hline \multirow[t]{2}{*}{ Hybrid seeds } & Wote & 69 & 31 & $15.2226^{* * *}$ \\
\hline & Nyando & 87 & 13 & \\
\hline \multirow[t]{2}{*}{ Ash } & Wote & 1 & 99 & 0.3365 \\
\hline & Nyando & 2 & 98 & \\
\hline \multirow[t]{2}{*}{ Irrigation } & Wote & 13 & 87 & $10.2130^{* * *}$ \\
\hline & Nyando & 28 & 72 & \\
\hline \multirow[t]{2}{*}{ Intercrop } & Wote & 96 & 4 & $13.8889^{* * *}$ \\
\hline & Nyando & 84 & 16 & \\
\hline \multirow[t]{2}{*}{ Legume fertilizer } & Wote & 100 & 0 & $8.2051^{* * *}$ \\
\hline & Nyando & 95 & 5 & \\
\hline \multirow[t]{2}{*}{ Vaccination } & Wote & 46 & 54 & $7.8644^{* * *}$ \\
\hline & Nyando & 54 & 46 & \\
\hline \multirow[t]{2}{*}{ Deworming } & Wote & 89 & 11 & 0.0321 \\
\hline & Nyando & 89 & 11 & \\
\hline \multirow[t]{2}{*}{ Antibiotics } & Wote & 67 & 33 & 0.4945 \\
\hline & Nyando & 63 & 37 & \\
\hline \multirow[t]{2}{*}{ Traditional } & Wote & 21 & 79 & 0.8696 \\
\hline & Nyando & 25 & 75 & \\
\hline \multirow[t]{2}{*}{ Spray/dip } & Wote & 53 & 47 & 1.5341 \\
\hline & Nyando & 59 & 41 & \\
\hline Improved breed & Wote & 7 & 93 & $53.1638^{* * *}$ \\
\hline
\end{tabular}




\begin{tabular}{lllll} 
& Nyando & 40 & 60 & $25.9611^{* * *}$ \\
Agroforestry & Wote & 47 & 53 & \\
& Nyando & 20 & 80 & \\
\hline
\end{tabular}

Preliminary diagnostics of the predictor variables to be used in the econometric analysis Multicollinearity and heteroscedasticity were tested on the socio-economic, farm and institutional variables. According to Wooldridge. (2013), multicollinearity is a state of high correlation between two or more explanatory variables. Multicollinearity test was conducted for continuous independent variables using variance inflation factor (VIF) see Table 2 , and for categorical independent variables using pairwise correlation (Table 3 ). Both results confirmed that there was no high linear relationship among continuous and categorical explanatory variables. Hence, no high correlation or strong association among all independent variables. Therefore, all the proposed potential explanatory variables were used in regression analysis. Both Breusch-Pagan and White test for Heteroskedasticity were also used to look for the evidence of association between the variance of the disturbance term and the explanatory variables without assuming any specific relationship.

Table 2. Variance Inflation Factor Test Results for Continuous Independent Variables

\begin{tabular}{lll}
\hline Variable & VIF & 1/VIF \\
\hline Log value of extension number & 1.79 & 0.5581 \\
Number of training attended & 1.77 & 0.5640 \\
Group diversity & 1.06 & 0.9463 \\
Household size & 1.05 & 0.953 \\
Proportion of land cultivated & 1.04 & 0.9619 \\
Age of the household head & 1.03 & 0.9681 \\
Distance to the market & 1.02 & 0.9802 \\
Mean VIF & 1.25 & \\
\hline
\end{tabular}

Table 3. Pair-Wise Correlation Test Results for Categorical Independent Variables

\begin{tabular}{lllllll}
\hline & site & gender & Educ. & land tenure & land slope off income \\
\hline Sub-county (site) & 1.0000 & & & & & \\
Gender of the household head & -0.0289 & 1.0000 & & & & \\
Education level of the head & -0.0951 & 0.5149 & 1.0000 & & & \\
Land tenure & 0.2189 & 0.0044 & -0.0336 & 1.0000 & & \\
Land slope & -0.0756 & 0.0067 & 0.0252 & -0.0421 & 1.0000 & \\
Off-farm income & 0.0116 & 0.1008 & 0.0330 & 0.0690 & -0.0433 & 1.0000 \\
\hline
\end{tabular}

The results presented in Table 4 present results for heteroskedasticity test. White test results indicated that the model was homoscedastic implying that the variance of the error term was constant hence we failed to reject the null hypothesis of homoscedasticity. In contrast, the Breusch-Pagan test result for homoscedasticity as indicated by a chi2 value of 28.51 and a p-value of 0 suggested presence of heteroskedasticity an indication that heteroskedasticity might be linear. Based on Breusch-Pagan result, the null hypothesis of constant variance of error term was rejected a conclusion that the model was heteroskedastic. This problem was solved by 
using robust standard errors as used in subsequent analysis.

Table 4: Test for Heteroskedasticity

\begin{tabular}{llcc}
\hline Type & chi2 & df & P \\
\hline White test & 78.06 & 101 & 0.9562 \\
Breusch-Pagan test & $28.51^{* * *}$ & 1 & 0.0000 \\
\hline$* * *$ Represent 1\% level of significance & & &
\end{tabular}

\section{Descriptive statistics}

The variables used in Multivariate Tobit Model were described and the descriptive statistics are shown in Table 5. Graphs in figure 4, 5, 6, and 7 also describe the good/food secured and bad/food insecure months of the year.

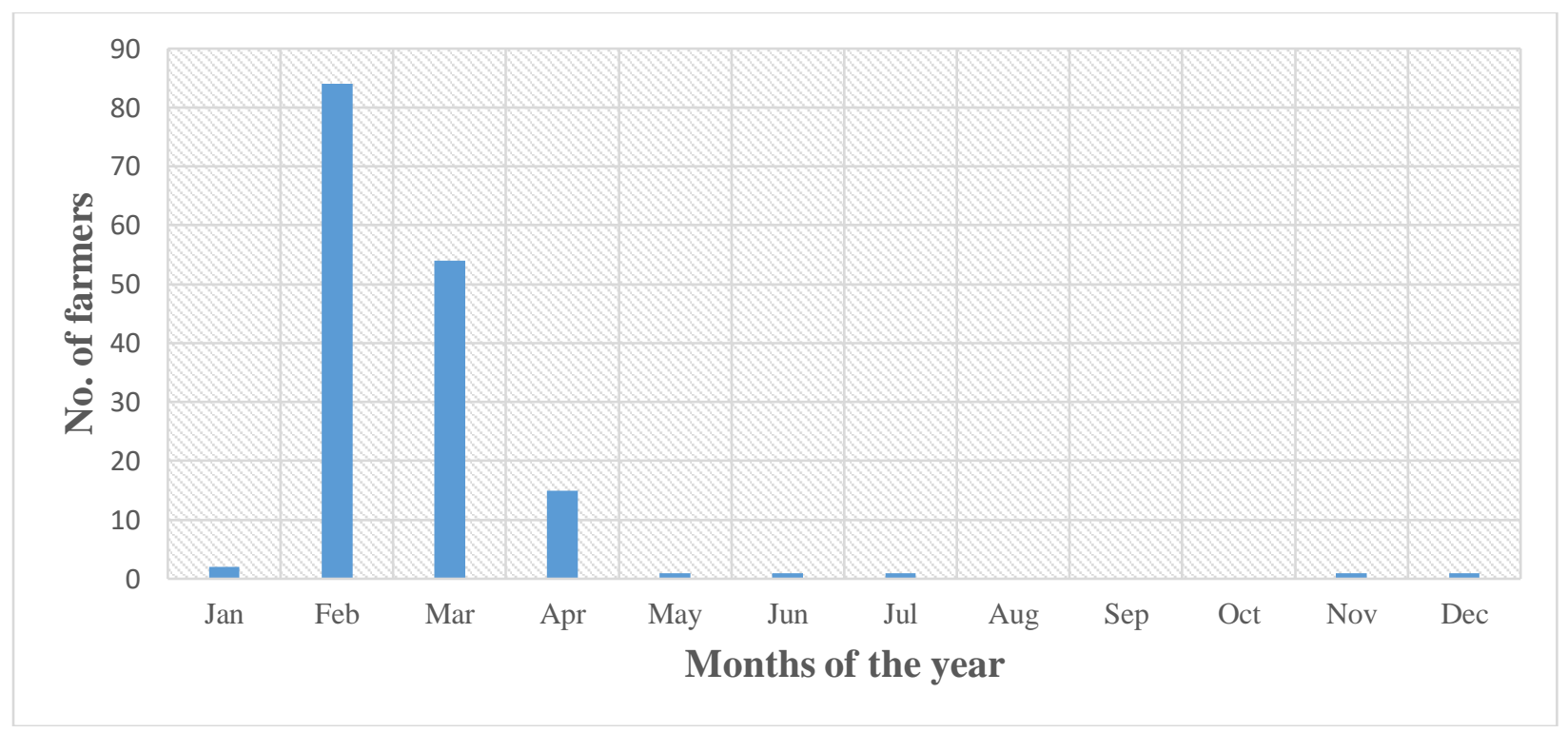

Figure 4: Makueni/Wote Sub-County food secured month 


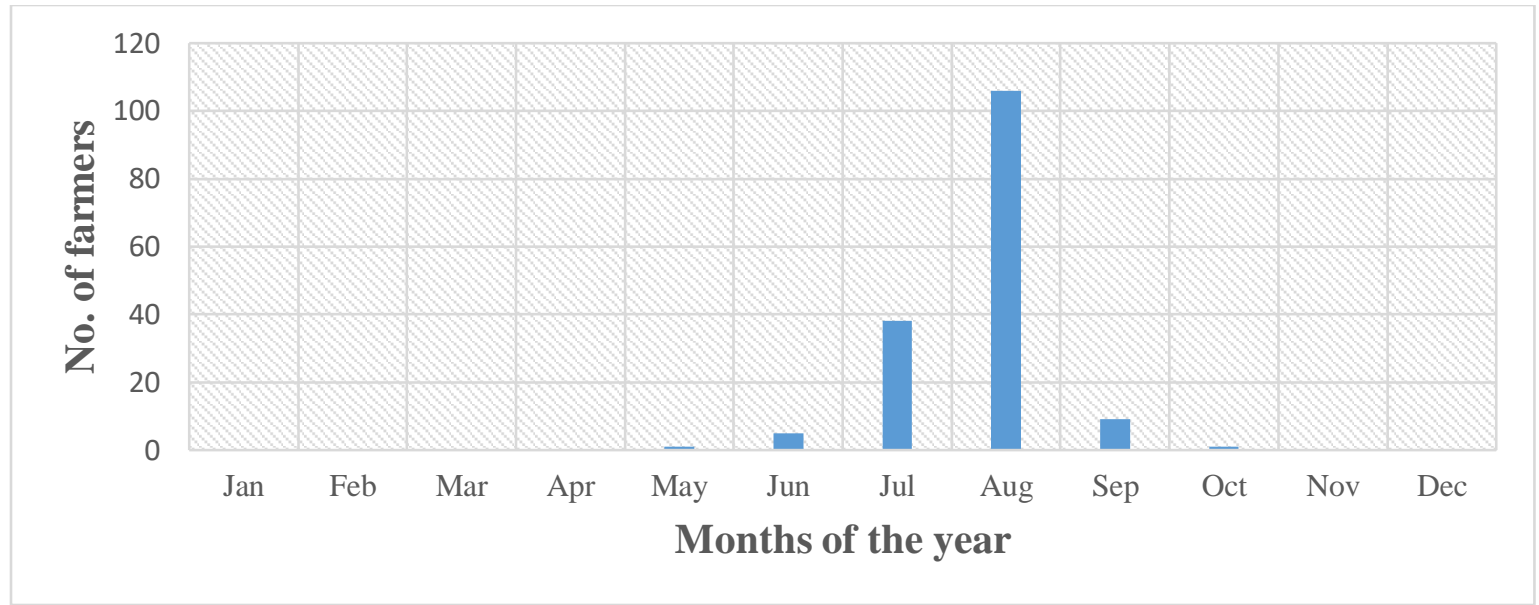

Figure 5: Nyando Sub-County food secured month

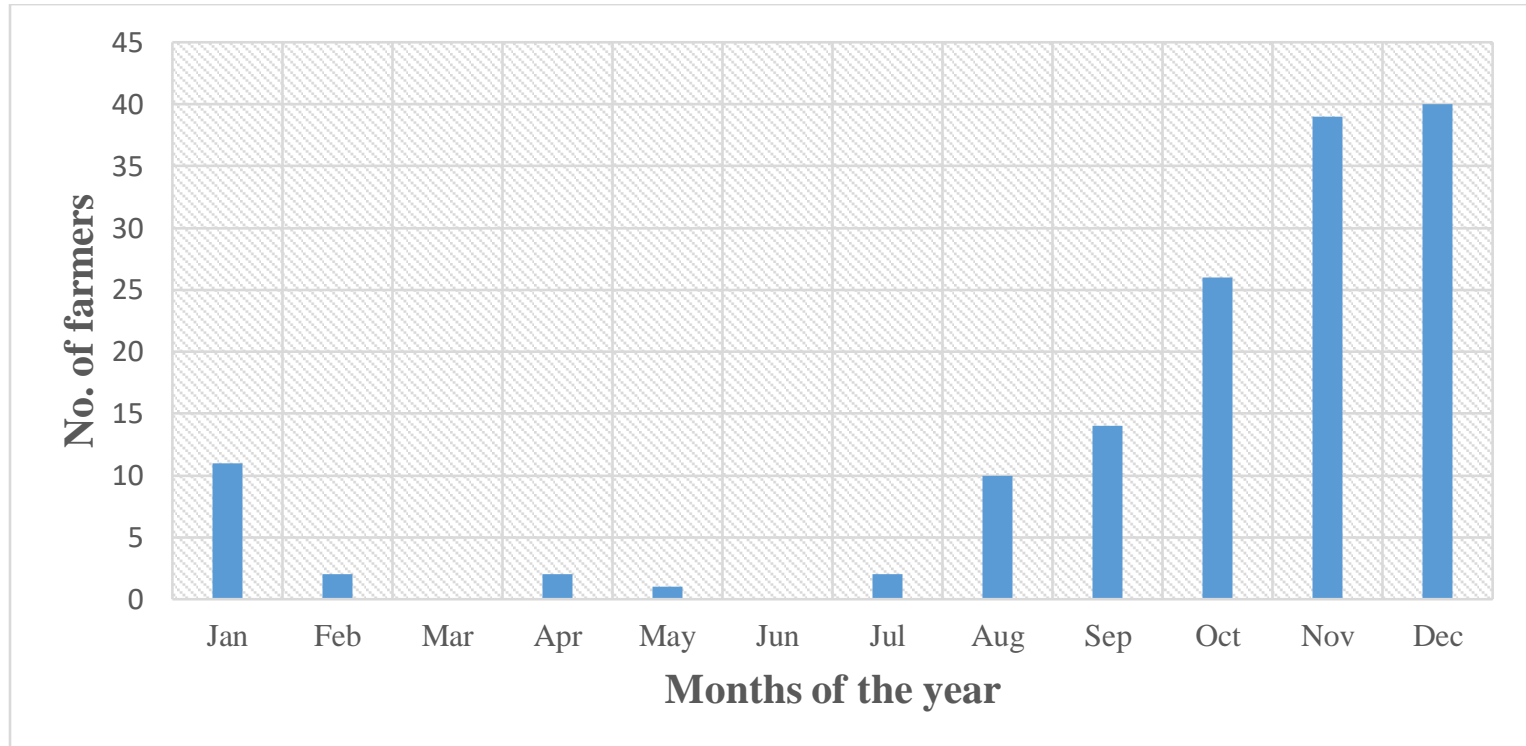

Figure 6: Makueni/Wote Sub-County food insecure month 


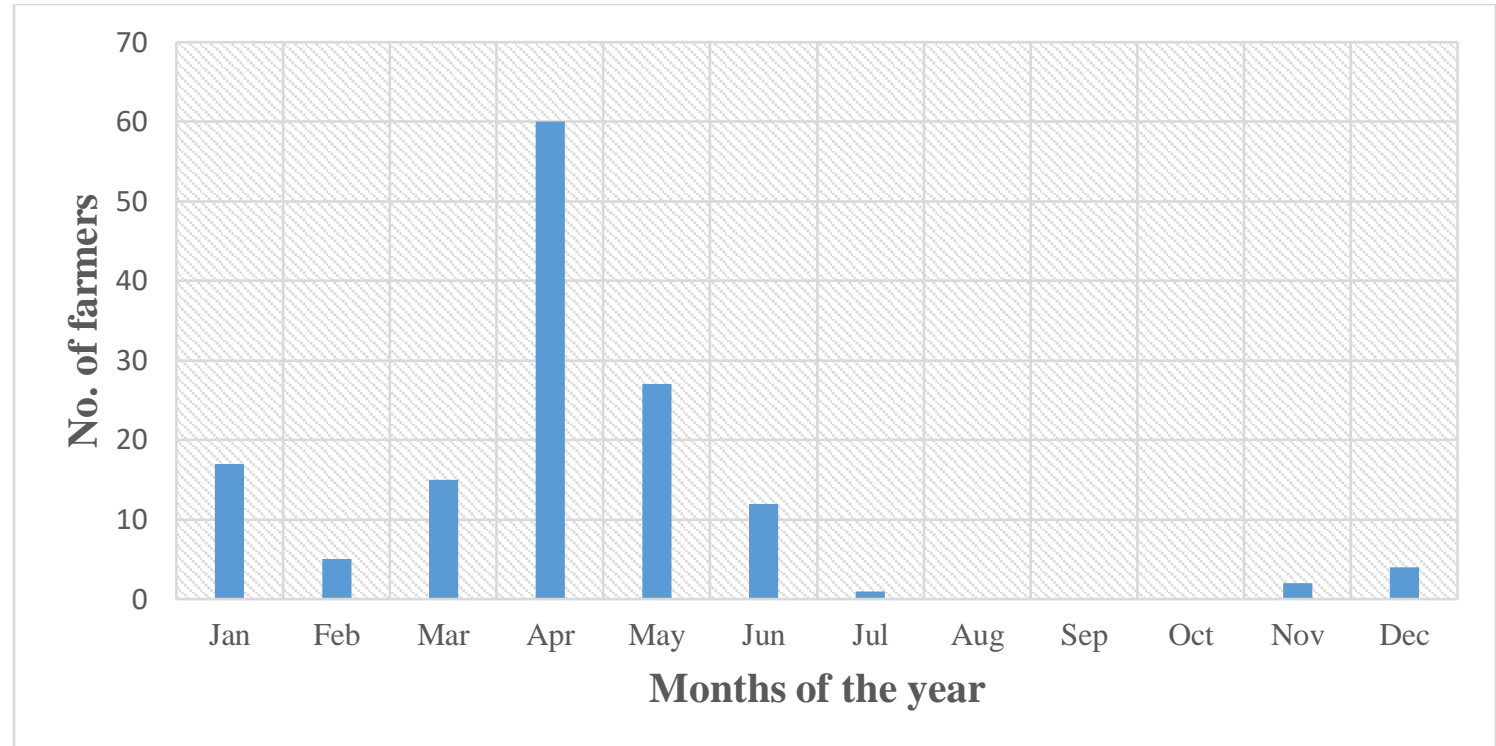

Figure 7: Nyando Sub-County food insecure month

Table 5. Description of Variables and Descriptive Statistics

\begin{tabular}{|c|c|c|c|c|c|}
\hline Variables & Variable Description & Mean & $\begin{array}{l}\text { Std. } \\
\text { Dev. }\end{array}$ & Min. & Max. \\
\hline \multicolumn{6}{|l|}{ (a) Dependent variables } \\
\hline FCSGM & $\begin{array}{l}\text { FCS for good month measured } \\
\text { from } 0 \text {, a food insecure } \mathrm{HH} \text { to } 80 \text {, } \\
\text { absolutely food secure } \mathrm{HH} \text {. }\end{array}$ & 62.49 & 11.33 & 17.5 & 80 \\
\hline FCSBM & $\begin{array}{l}\text { FCS for bad month measured } \\
\text { from } 0 \text {, a food insecure } \mathrm{HH} \text { to } 80 \text {, } \\
\text { absolutely food secure } \mathrm{HH} \text {. }\end{array}$ & 49.54 & 14.45 & 9.5 & 80 \\
\hline PPI & $\begin{array}{l}\text { Continuous from } 0=\text { low to } \\
100=\text { high probability of living } \\
\text { below poverty line }\end{array}$ & 51.14 & 14.66 & 18 & 93 \\
\hline \multicolumn{6}{|l|}{$\begin{array}{l}\text { (b) Independent } \\
\text { variables } \\
\text { Socio-economic } \\
\text { characteristics }\end{array}$} \\
\hline $\begin{array}{l}\text { Age of the household } \\
\text { head }\end{array}$ & Age of household head (years) & 55.28 & 15.40 & 22 & 103 \\
\hline $\begin{array}{l}\text { Gender of the household } \\
\text { head } \\
\text { Education level of the }\end{array}$ & $\begin{array}{l}\text { Dummy }=1 \text { if household head is } \\
\text { male, } 0 \text { otherwise } \\
\text { Categorical from } 1=\text { low to } 5=\text { high }\end{array}$ & 0.75 & 0.43 & 0 & 1 \\
\hline head & & 1.96 & 1.05 & 0 & 4 \\
\hline Household size & $\begin{array}{l}\text { Number of people in the } \\
\text { household } \\
\text { Household engaged in off-farm }\end{array}$ & 5.82 & 2.83 & 1 & 23 \\
\hline $\begin{array}{l}\text { Off-farm income } \\
\text { Farm characteristics }\end{array}$ & activity 1,0 otherwise & 0.92 & 0.27 & 0 & 1 \\
\hline
\end{tabular}




\begin{tabular}{|c|c|c|c|c|c|}
\hline Land market participation & $\begin{array}{l}\text { Whether household participate } 1 \text {, } \\
0 \text { otherwise } \\
\text { Categorical from } 1=\text { flat to }\end{array}$ & 0.57 & 0.21 & 0 & 1 \\
\hline Land slope & $4=$ steep slope & 2.00 & 1.08 & 1 & 7 \\
\hline $\begin{array}{l}\text { Proportion of Land } \\
\text { cultivated } \\
\text { Institutional } \\
\text { characteristics }\end{array}$ & $\begin{array}{l}\text { Proportion cultivated to total } \\
\text { land accessed }\end{array}$ & 0.66 & 0.82 & 0.03 & 11 \\
\hline Distance to the market & $\begin{array}{l}\text { Distance to agricultural product } \\
\text { market }(\mathrm{km}) \\
\text { Number of agricultural trainings }\end{array}$ & 3.20 & 2.93 & 1 & 20 \\
\hline Number of trainings & $\begin{array}{l}\text { attended by hhh } \\
\text { Number of groups mature }\end{array}$ & 0.68 & 1.33 & 0 & 11 \\
\hline Group diversity & $\begin{array}{l}\text { household members belong to } \\
\text { Logarithm of extension services }\end{array}$ & 2.17 & 1.98 & 0 & 18 \\
\hline Log extension number & accessed per year & 0.14 & 0.36 & 0 & 2.4 \\
\hline Site/Location & Dummy, $0=$ Wote or $1=$ Nyando & 0.50 & 0.50 & 0 & 1 \\
\hline
\end{tabular}

The Food secured months and Food Insecure months of the Year

The two sites of the study differ in seasonality even though they both have two rainy seasons in a year, but harvesting in both sub-counties is normally experienced once in one major season of the year. In Nyando Sub-County the best month is August when most crop harvesting take place and its worst month is April, while in Makueni/Wote Sub-County the best month is February and its worst months are November and December respectively. These are shown in Figures 4 - 7.
Diagnostics Statistics for the Multivariate Tobit Model

To determine the role of agricultural intensification practices on smallholder livelihood outcomes, Multivariate Tobit model was used for analysis. Table 6 shows the results of Multivariate Tobit Model. The dependent variables are Progress out of Poverty Index (PPI), Household Food Consumption Score (HFCS) for the Good month and for the Bad month. Tests for the goodness of fit indicated that the data fits the model reasonably well. The Wald test that all regression coefficients are jointly equal to zero is rejected (Wald chi-square $(40)=208.13$; Prob $=$ 0.0000 ). Meaning all independent variables are statistically significant. The Likelihood Ratio Test (LR Test:

Table 6: Results of the Multivariate Tobit Regression for Household Food Consumption Score and Progress out of Poverty Index

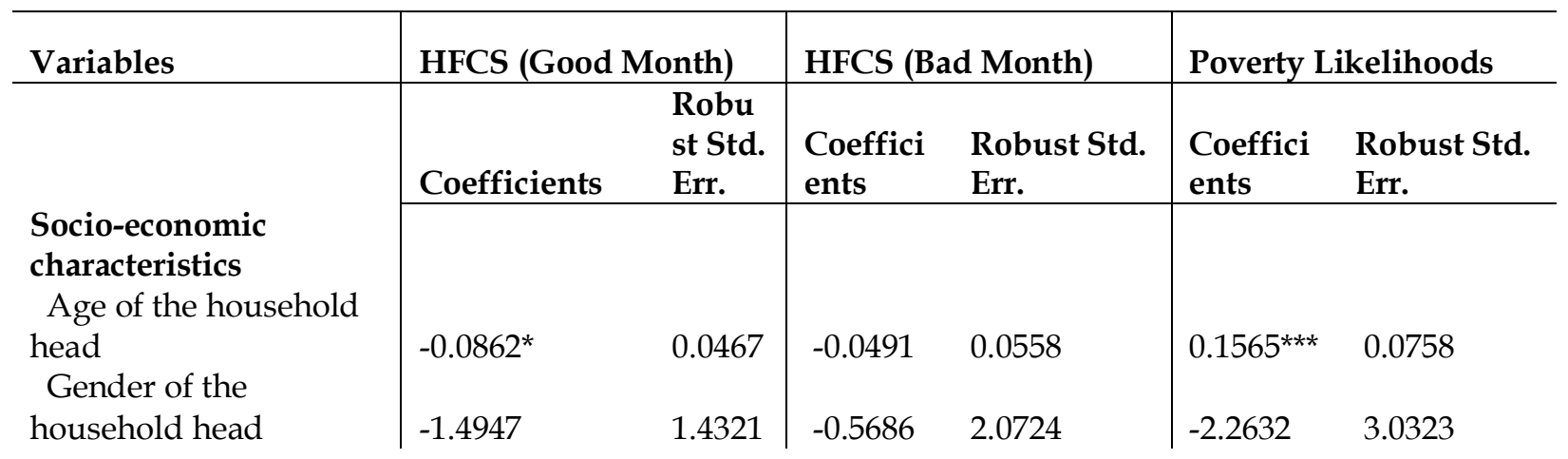




\begin{tabular}{|c|c|c|c|c|c|c|}
\hline $\begin{array}{l}\text { Education level of the } \\
\text { head }\end{array}$ & -0.4449 & 0.7266 & 0.4966 & 0.9009 & - & - \\
\hline Household size & $0.7238^{* * *}$ & 0.1857 & $0.5684^{*}$ & 0.3126 & - & - \\
\hline Off-farm income & 0.0755 & 2.2835 & 0.0435 & 2.8368 & 4.2645 & 3.8346 \\
\hline $\begin{array}{l}\text { Farm characteristics } \\
\text { Land market } \\
\text { participation }\end{array}$ & $-4.2764^{* *}$ & 1.7500 & -2.5607 & 1.8609 & -2.2675 & 2.9261 \\
\hline $\begin{array}{l}\text { Land slope } \\
\text { Proportion of Land } \\
\text { cultivated } \\
\text { Institutional } \\
\text { characteristics }\end{array}$ & $\begin{array}{l}-0.6352 \\
1.6992^{* * *}\end{array}$ & $\begin{array}{l}0.5858 \\
0.4832\end{array}$ & $\begin{array}{l}-0.8535 \\
2.1389 * *\end{array}$ & $\begin{array}{l}0.6398 \\
0.8468\end{array}$ & $\begin{array}{c}1.4949 \\
-2.7583^{*}\end{array}$ & $\begin{array}{l}1.0560 \\
1.5255\end{array}$ \\
\hline Distance to the market & 0.2072 & 0.1881 & $\begin{array}{l}1.0056^{* * *} \\
-\end{array}$ & 0.2484 & -0.3572 & 0.4409 \\
\hline Number of trainings & $-0.8749^{*}$ & 0.4942 & $1.4865^{* *}$ & 0.7599 & 1.4765 & 1.1426 \\
\hline Group diversity & $1.0104^{* * *}$ & 0.2849 & $1.2824^{* * *}$ & 0.3550 & $1.7200^{* *}$ & 0.5137 \\
\hline $\begin{array}{l}\text { Sub-county (site) } \\
\text { Log of extension }\end{array}$ & $3.4004^{* * *}$ & 1.3273 & $9.1319^{* * *}$ & 1.7094 & 3.8703 & 2.8155 \\
\hline number & 0.9018 & 1.8615 & 3.2853 & 2.6410 & -6.1201 & 4.1374 \\
\hline Level of Intensification & -1.0039 & 0.7695 & $1.5970^{*}$ & 0.9117 & $-2.9829^{*}$ & 1.5587 \\
\hline Constants & 67.0631 & 5.9931 & 25.5541 & 7.5472 & 24.7930 & 10.1283 \\
\hline
\end{tabular}

Number of obs $=320$

Iteration log pseudolikelihood $=$ -

3803.578

Wald chi2 $(40)=208.13$, Prob $>$ chi2 $=0$

LR Test: $\operatorname{chi} 2(3)=103.479$, Prob $>$ chi $2=0$

$*, * *, * * *$ Represent 10,5 and $1 \%$ levels of significance respectively

chi-square $(3)=103.479$, Prob $>$ chi-square $=0$ ) compares this model to other alternative models which is the individual Tobit models for three regressions. The LR Test is highly significant at $1 \%$ level, meaning the data fits Multivariate Tobit Model well.

This study estimated both good/food secured months and the bad/food insecure months household food security using HFCS as a function of level of agricultural intensification practices, household socio-economic, farm and institutional characteristics. The results from Table 6 indicated those factors which significantly influenced household food security both for food secure and food insecure months include location site, household size, number of trainings, group diversity, proportion of land cultivated while intensification level and distance to the market only affected food security during bad months whereas age of the household head only affected food security during good months. Estimate of factors influencing poverty status of smallholder households was not as robust as those affecting food securities of the same households. This was because in poverty regression some variables were dropped because they were used to generate poverty scores. These variables were household size and education level of the household head which could have caused reverse causality where the dependent variable could be a function of independent 
variable. Including such variables would lead to endogeneity problem meaning the estimates can be biased causing underestimation or overestima tion.

\section{Discussions}

From the result in Table 6, age of the household head had a negative and significant influence on food security status for the good/food secured month at 10 percent level of significance, as well as a positive and significant effect on poverty status of the household at 5 percent level of significance. These results could imply that older farmers tend to have a low receptivity towards newly introduced agricultural technologies since they are more likely to be conservative with their traditional ways of farming which results in low agricultural output and income hence, they become less food secure. Furthermore, older farmers might lack incentive to attend agricultural training that would enable them learn how to engage in and the importance of agricultural intensification practices thus making them less food secure compared to younger farmers. Similar finding was found by Onasanya and Obayelu (2016) and Yahaya et al. (2017) who argued that younger farmers were likely to be more innovative and were more interested in learning activities thereby increasing their awareness to participate in the trainings and uptake of agricultural intensification practices for improved agricultural production and incomes compared to their elderly counterparts.

A positive and significant effect of household age on poverty status could also be attributed to the fact that older farmers are less energetic, less mobile and lacks flexibility, and thus negatively influence their awareness of the new agricultural technologies than younger household heads. This negatively affects their productivity, output, income and consumption expenditure thus leading to higher level of poverty among them than younger household head. This is similar to the findings of Wodajo (2017) who asserted that increase in age of the household head increases the vulnerability of these households to poverty due to lack of mobility.
Household size was found to be positively and significantly influencing food security. For the good month it is highly significant at 1percent while for the bad month, it is significant at 10 percent. This is because more household members mean more labour leading to more output hence more food production. Large family size also gives more family labour to the farm which reduces labour cost and the saved money can be spent in purchasing food thereby improving the food security status of the household. Family labour is also of high quality compared to hired one as members are tender, thorough and takes sufficient care because the farm, products and all benefits belong to them these leads to higher food production hence improved food security, this is in line with (Obayelu, 2012). This finding is in contrast with Asghar and Muhammad, (2013), Silvia et al. (2015) and Bashir et al. (2013) finding that the size of the household is positively associated with food insecurity of the household as food secure households are fewer in size compared to their counterparts because resources to be shared are limited.

Some smallholder farmers households interviewed operated on their own land exclusively, while others operated on owned land as well as rented in or rented out land. Those who own land as well as renting in or out part of the land was classified as farmers participating in land markets while those who operated strictly on own land were none participants of land market. From the results it was found that land market participation has a negative significant influence on food security during the good season at 5 percent level. This implies that farmers who participated in land market either by renting in or renting out their plot were less food secure compared to those who operated on their own land exclusively. This was attributable to the fact that land rented in these study sites are degraded leading to lower production. The other reason is likely to be the effects of information asymmetry which is present in land market. For instance, due to information asymmetry, a farmer might find himself buying a less productive land or a farmer might end up renting out his productive land thus resulting to low crop production. This finding is in contrast with 
O'Neill and Hanrahan, (2012) who found that good soil quality leads to increased land renting.

Proportion of land allocated for crop cultivation had a positive significant effect on food security and a negative significant effect on poverty status of the household. This implied that households who allocated a greater proportion of their land for crop cultivation were more food secure than those who allocated small proportions of their land for crop cultivation. This was because households with large land sizes had the capacity to produce more crops thus increasing their food production hence were more food secure. This finding is in line with Shiferaw et al. (2014) who reported that the likelihood of food security increases in proportion to increase in the area dedicated to improved wheat varieties. On the other hand, households with more land under cultivation were more likely to live above the poverty line. Large cultivated land enables farmers to produce more crops which can be sold hence generate income for the household leading to a reduction in poverty status. More land cultivated means several crops can be allocated portions in the farm and the farmers can easily diversify, a strategy to reduce the vulnerability of harsh climatic conditions in order to increase yield hence alleviating poverty. According to Abebe (2017), households with large tracks of land have enhanced welfare than those with smaller land sizes because they can produce more crops. In contrary, Kassie et al. (2011) argued that households with small farm sizes had a tremendous reduction in poverty than households with large land sizes.

Distance to the market had a positive and high significant effect on food security at 1 percent significant level only during the bad month. Meaning those who are far from the market are comparatively food secure during bad season than those closer to the market. This finding is in contrast to the normal economic belief that market access is the place where households can purchase any food item throughout the year. A positive relationship between distance to the market and food security during bad month can be explained by the fact that households who are far from the market are less likely to sell their farm produce during harvesting time or good months. They store much of their produce which they consume at difficult time of the year. Smallholder farmers who reside far from the market realize increase in transaction cost which discourage them from market participation during harvesting period when prices are low. This makes households far from the market more food secure than their counterparts who are closer to the market who are normally encouraged or attracted to sell their produce to the market during harvesting time, because they need cash then rely on market supply later when food prices are at the peak. This finding is in line with Zakari et al. (2014), that most farm households even though are closer to the market where food is available, lack purchasing power during difficult times of the year as they sell most of their produce at lower prices during harvesting period and demand these food again from the markets when prices are high.

Number of trainings attended by household members for both good months and bad months were found to be negatively influencing food security and significant at 10 percent and 5 percent respectively. Training should upgrade the skills of farmers in order to effectively implement agricultural intensification practices to increase food production. This is only possible depending on how efficiently and effectively training was delivered to farmers. Training in this study negatively affected food security, this is an indication that there is high likelihood that farmers do not apply what they learnt from training. Training should be farmers demand driven, that is farmers are craving for it but it seems that those who attended training were inclined to either allowances or other benefits best known to them. The other reason for this might be that training was too general and not farmers or farm specific in nature. It might also be that the mode of delivery was not adequate to lead to a substantial impact on food production. This finding is in contrast to Yahaya et al. (2018) result that households who participated in sustainable agricultural intensification practices training were more likely to have improved access to food. Training was expected to transfer important agricultural knowledge and skills which is beneficial to farmers improving food production (Stewart et al., 2016). 
Group diversity was significant and found to be positively and negatively influencing food security and poverty status at 1 percent and 5 percent level, respectively. A household whose members belong to several groups were more food secure. This is because group membership promotes social capital as a platform where they share knowledge, experiences and even can give, lend and borrow food items when in need thus enabling smallholder farmers to overcome credits and resource constraints which reduce food insecurity. This finding is in line with Kassie et al. (2014), who stated that membership of households to farmer groups decreases their likelihood of severe food insecurity because social networks are important resource that households can use to help in alleviating the effect of adverse shocks. On the other hand, households who belonged to many groups were less likely to be poor than those belonging to few groups. Having members of different groups with different background brings in variety of information, experience as well as knowledge to be exchanged. Household members in groups can easily access credit than those who do not belong to any group this is because group members act as collateral. Borrowed funds can also be put into development use which improves the welfare of these households hence alleviate their poverty status. Teklewold et al. (2013), found that social capital and networks are crucial in influencing diffusion of most sustainable agricultural practices in Ethiopia leading to poverty alleviation

Location/Site matters in explaining food security status of smallholder farmers' household in the two regions. With site dummies, Wote/Makueni Sub-County was used as a base category and assumes 0 and 1 for households from Nyando Sub-County. Nyando had a positive coefficient and was statistically significant at 1 percent level of significant. Both Sub-Counties are subject to low and unevenly distributed rainfall and agricultural intensification is vital in reducing farm households' vulnerability to effect of climate change on food security. Smallholder farmers do not necessarily get their food sources from own farm production but can also obtain food from other sources like purchasing, food aid and gifts, hunting and gathering from forest and lakes among other sources. The significant difference might be because Nyando Sub-County was surrounded by agriculturally high productive areas which supply their markets with foodstuffs at reasonable prices. It might also be as a result of good road network which makes transportation cost of goods and other foodstuffs from neighbouring sub-counties comparatively cheaper. This finding is supported by Kristjanson et al. 2012 who found that locations/sites differ respectively with the total number of changes in farming systems over the years. Similarly, Wodajo (2017), also affirmed that Locations which has less economic opportunities with weak social protection and networks have higher degrees of food insecurity.

The results also indicate that level of agricultural intensification significantly influenced food security for the bad month and poverty level of smallholder farmers' households. The influence of agricultural intensification on food security for the bad month was positively significant at 10 percent level. On the other hand, the influence of agricultural intensification on poverty was negative and significant at 10 percent. This implies that the higher level of agricultural intensification the higher the likelihoods of being food secure as well as leaving above the poverty line due to increased agricultural productivity, output, income, and consumption expenditure. Another likely reason for this result is that the adoption of more agricultural intensification practices might help in improving soil conditions as well as alleviating the adverse effect of climate change thus leading to improved agricultural productivity, increase in surplus yield and incomes which translate to food security and poverty alleviation among smallholder households. This finding is also in line with Kassie et al. (2011) who stated that the adoption of agricultural intensification practices such as improved groundnut seed variety increases crop income thus leading to poverty reduction. Khonje et al. (2015), also found that technology adoption increases agricultural production and farm productivity hence reduces poverty and improves food security.

\section{Conclusions}

The results showed that farm households who belong to many groups as well as those who 
allocated a greater proportion of their land for agricultural production were more food secure and least likely to be poor. The results further indicated that level of agricultural intensification has the potential of contributing to the improvement of food security and a high probability of poverty reduction for rural smallholder farmers' households. Thus, intensive use of agricultural practices in the semi-arid rural areas will lead to increased food security and reduced household probability of being poor. Policies should be formulated by ILRI and CCAFS to motivate households to form and join groups as well as encouraging them to utilize larger proportion of their land for agricultural production. There is need for the government and CCAFS/ILRI to develop and disseminate incorporation of both traditional and new agricultural practices which are production

\section{References}

Abdulai, A. \& Huffman, W. (2014). The adoption and impact of soil and water conservation technology: An endogenous switching regression application. Land Economics, 90(1): 26-43

Abebe, F. E. (2017). Determinants of rural households' vulnerability to poverty in Chencha and Abaya Districts, Southern Ethiopia. International Journal of Development Research, 7(1), 11119-11130.

Abukari, Y. (2014). Livelihood strategies and the determinants of subjective wellbeing, (Masters Thesis). Kwame Nkrumah University of Science and Technology, Ghana.

AGRA - Alliance for a Green Revolution in Africa. (2014). African Agriculture Status Report: Climate Change and Small holder Agriculture in sub-Saharan Africa. AGRA Report Issue Number 2, pp6-34.

Agula, C., Akudugu, M. A., Dittoh, S. \& Mabe, F. N. (2018). Promoting sustainable agriculture in Africa through ecosystem based farm management practices: evidence from Ghana. Agriculture \& Food Security, 1-11.

Alkire, S. \& Santos, M. E. (2014). Measuring Acute Poverty in the Developing World: Robustness and Scope of the Multidimensional Poverty Index. World Development, 59, 251-274. context specific and also come up with interventions which are generation specific, easily incorporated by both the young and the old. This can be achieved by reaching them through their social network platforms. Finally, farmers should be encouraged to carry out multiple agricultural intensification practices through multi-stakeholder training and education in order to boost their food security status and reduce their vulnerability to poverty.

\section{Acknowledgement}

The author thanks all farmers who provided useful information for this research and extends gratitude to CCAFS/ILRI for funding all data collection exercise.

Amekawa, Y., Sseguya, H., Onzere, S., \& Carranza, I. (2010). Delineating the multifunctional role of agroecological practices: toward sustainable livelihoods for smallholder farmers in developing countries. Journal of Sustainable Agriculture, 34(2), 202-228.

Anastasopoulos, P. C. (2016). Random parameters multivariate tobit and zeroinflated count data models: Addressing unobserved and zero-state heterogeneity in accident injury-severity rate and frequency analysis. Analytic Methods in Accident Research, 11, 17-32.

Asghar, Z. \& Muhammad, A. (2013). Socioeconomic determinants of household food insecurity in Pakistan. Mpra paper 21510, University Library of Munich, German.

Ayuya, O. I. (2018). Towards being equal to them: Impact of organic certified production systems on women empowerment in agriculture. African Journal of Agricultural Research, 13(16), 821-833.

Bashir, M. K., Schilizzi, S. \& Pandit, R. (2013). Regional sensitivity of rural household food security: The case of Punjab, Pakistan. The Journal of Animal \& Plant Sciences, 23(4), 1200-1206.

Beyene, F. (2014). Determinants of food security under changing land-use systems among pastoral and agro-pastoral households in eastern Ethiopia. Environ Dev Sustain, 1-20. 
Binswanger-mkhize, H. P. \& Savastano, S. (2016). Agricultural intensification: The status in six African countries. Food Policy, 67, 1-15.

Boka, G. T. (2017). Climate change challenges, smallholders' commercialization, and progress out of poverty in Ethiopia. Working Paper Series, (253).

Bommarco, R., Kleijn, D. \& Potts, S. G. (2013). Ecological intensification: Harnessing ecosystem services for food security. Trends in ecology \& evolution, 28(4), 230-238.

Bryan, E., Ringler, C., Okoba, B., Roncoli, C., Silvestri, S. \& Herrero, M. (2013). Adapting agriculture to climate change in Kenya: Household strategies and determinants. Journal of Environmental Management, 114, 26-35.

Chartres, C.J., \& Noble, A. (2015). Sustainable intensification: overcoming land and water constraints on food production. Food Sec. 7, 235-245. https://doi.org/10.1007/s12571015-0425-1

Colin Thor West. (2019). Domestic Transitions, Desiccation, Agricultural Intensification, and Livelihood Diversification among Rural Households on the Central Plateau, Burkina Faso. American Anthropologist 111(3), 275-288

Delve, R., Benfica, R. M., Rusike, J., Harawa, R., Keizire, B., Bigirwa, G. \& Ininda, J. (2016). Africa agriculture status report 2016: Progress towards agricultural transformation in SubSubsaharan Africa. Retrieved from https://agra.org/aasr2016/public/assr.pd $\mathrm{f}$.

Desiere, S., Vellema, W. and Haese, M. D. (2015). A validity assessment of the Progress out of Poverty Index ( PPI ) TM. Evaluation and Program Planning, 49, 10-18.

Dobermann, A., Nelson, R., Beever, D., Bergvinson, D., Crowley, E., Denning, G. \& Lynam, J. (2013). Solutions for Sustainable Agriculture and Food Systems. Retrieved fromhttp://unsdsn.org/resources/publica tions/solutions-for-sustainableagriculture-and-food-systems /

FAO. (2015). 17 Sustainable development goals. Retrieved 21 November, 2017 from www.fao.org/post-2015-mdg

Grameen Foundation, (2018). Poverty Probability Index. Retrieved from http//www.progressoutofpoverty.org. On
August 22nd, 2018.

Government of Kenya. (2010). Agricultural sector development strategy 2010-2020. Ministry of Agriculture, Nairobi, Kenya: government printer.

Goverment of Kenya (2013a). Makueni first county integrated development plan 2013-2017. Makueni County Government press.

Government of Kenya (2013b). Kisumu first county integrated development plan 2013-2017. Kisumu County Government press.

Government of Kenya (2015). Agricultural policy.Ministry of Agriculture, Livestock and Fisheries. Nairobi: Government Printer.

Government of Kenya (2017). Kenya Climate Smart Agriculture Strategy-2017-2026. Ministry of Agriculture, Livestock and Fisheries. Nairobi, Kenya: government printer.

Gujarati, D. N. (2003). BASIC ECONOMETRICS. (McGraw-Hill Higher Education 'EZ, Ed.) (FOURTH EDI). West Point: McGraw-Hill Higher Education 'EZ.

Hammond, J., Fraval, S., van Etten, J., Suchini, J. G., Mercado, L., Pagella, T., ... van Wijk, M. T. (2015). The Rural Household MultiIndicator Survey (RHoMIS) for rapid characterisation of households to inform climate smart agriculture interventions. Agricultural Systems, 151: 225-233.

Headey, D. \& Ecker, O. (2013). Rethinking the measurement of food security: from first principles to best practice. Food Security, 5: 327-343.

Hussain, I. \& Hanjra, M. A. (2004). Irrigation and poverty alleviation: Review of the empirical evidence. Irrigation and Drainage 53, 1-15.

Ickowitz, A., Powell, B., Rowland, D., Jones, A. \& Sunderland, T. (2019). Agricultural intensification, dietary diversity, and markets in the global food security narrative. Global Food Security 20, 9-16

Issahaku, G. \& Abdulai, A. (2019). Can Farm Households Improve Food and Nutrition Security through Adoption of Climatesmart Practices? Empirical Evidence from Northern Ghana. Applied Economic Perspectives and Policy, 0(0), 1-22.

Johannes Woelcke. (2006). Technological and policy options for sustainable agricultural intensification in eastern Uganda. 
Agricultural Economics 34 (2), 129-139

Kassie, M., Ndiritu, S. W. \& Stage, J. (2014). What Determines Gender Inequality in Household Food Security in Kenya? Application of Exogenous Switching Treatment Regression. World Development, 56: 153-171.

Kassie, M., Shiferaw, B. \& Muricho, G. (2011). Agricultural Technology, Crop Income, and Poverty Alleviation in Uganda. World Development, 39(10), 1784-1795.

Khonje, M., Manda, J., Alene, A. D. \& Kassie, M. (2015). Analysis of Adoption and Impacts of Improved Maize Varieties in Eastern Zambia. World Development, 66, 695-706.

Kennedy, G., Berardo, A., Papavero, C., Horjus, P., Ballard, T., Dop, M., Delbaere, J. \& Brouwer, I . D. (2010). Proxy measures of household food consumption for food security assessment and surveillance: comparison of the household dietary diversity and food consumption scores. Public Health Nutrition, 13(12): 2010-2018.

Kok, M., Lu“deke, M., Lucas, P., Sterzel, T., Walther, C., Janssen, P., Sietz, D. \& Soysa, I. (2016). A new method for analysing socioecological patterns of vulnerability. Environmental Change 16, 229-243.

KNBS. (2016). Economic survey 2016. Nairobi, Kenya: Government of Kenya printing press.

Kristjanson, P., Neufeldt, H., Gassner, A., Mango, J., Kyazze, F. B., Desta, S. \& Coe, R. (2012). Are food insecure smallholder households making changes in their farming practices? Evidence from East Africa. Food Security, 4, 381-397.

Leigh, A., Ricker-gilbert, J. \& Florax, R. J. G. M. (2014). How does population density influence agricultural intensification and productivity? Evidence from Ethiopia. Journal of Food Policy, 48, 1-11.

Marenya, P. P. \& Barrett, C. B. (2005). Household level determinants of adoption of improved natural resources management practices among smallholder farmers in western Kenya. Rockefeller Foundation (Institution), 32(4), 515-536.

Maziya, M., Mudhara, M., \& Chitja, J. (2017). What factors determine household food security among smallholder farmers? Insights from Msinga, KwaZulu-Natal,
South Africa. AGREKON 56(1), 40-52.

MoALF. (2015). Economic review of agriculture 2015. Nairobi: Government of Kenya printing press.

Moebius, B. N., Ngoze, S., Lehmann, J. \& Van Es, H. M. (2014). Long-term soil quality degradation along a cultivation chronosequence in Western Kenya.Agriculture, Ecosystems $\mathcal{E}$ Environment, 141(1-2), 86-99.

Mugi-Ngenga, E. W., Mucheru-Muna, M. W., Mugwe, J. N. \& Ngetich, F. K. (2016). Household's socio-economic factors influencing the level of adaptation to climate variability in the dry zones of Eastern Kenya. Journal of Rural Studies, 43, 49-60.

Muriithi, A. G., Bett, E. \& Ogaleh, S. A. (2009). Information technology for agriculture and rural development in Africa: Experiences from Kenya. A paper presented atConference on International Research on Food Security, Natural Resource Management and Rural Development,University of Hamburg, German October 6-8, 2009.

Nata, J. T., Mjelde, J. W. \& Boadu, F. O. (2014). Household adoption of soil-improving practices and food insecurity in Ghana. Agriculture \& Food Security, 3(17), 1-12.

Obayelu, A. E. (2012). Households' food security status and its determinants in the NorthCentral Nigeria. Food Economics, 9(4), 241256.

OECD/FAO. (2016). OECD-FAO Agricultural outlook 2016-2025. Paris, France: OECD Publishing.

Oluwatayo, I. B. \& Ojo, A. O. (2016). Is Africa's dependence on agriculture the cause of poverty in the continent? An empirical review. The Journal of Developing Areas, 50(1), 93-102.

Olwande, J., Sikei, G. \& Mathenge, M. (2009). Agricultural technology adoption: A panel analysis of smallholder farmers' fertilizer use in Kenya. A paper presented at the May 2009 Conference on "Agriculture for Development in Sub-Saharan Africa," Mombasa, Kenya, 7th January, 2009.

Onasanya, O. A., \& Obayelu, O. A. (2016). Determinants of food security status of maize-based farming households in 
Southern Guinea Savannah area of Oyo State, Nigeria. Turkish Journal of Agriculture, 4(5), 411-417.

O'Neill, S \& Hanrahan, K. (2012). Decoupling of agricultural support payments: the impact on land market participation decisions. European Review of Agricultural Economics 39 (4), 639-659.

Prokhorov, A. \& Schmidt, P., (2009). Likelihoodbased estimation in a panel setting: robustness, redundancy and validity of copulas. Journal of Econometrics, 153(1), 93 104.

Raut, N., Sitaula, B. K. \& Bajracharya, R. M. (2010). Agricultural intensification: linking with livelihood improvement and environmental degradation in mid-hills of Nepal. The Journal of Agriculture and Environment, 11, 1-12.

Ravallion, M. (2013). How Long Will It Take to Lift One Billion People Out of Poverty? Policy Research Working Paper; No. 6325. World Bank, Washington, DC. (c) World Bank.

https://openknowledge.worldbank.org/h andle/10986/12166 License: CC BY 3.0 IGO.

Rufino, M. C., Quiros, C., Boureima, M., Desta, S., Douxchamps, S., Herrero, M., ... Wanyama, I. (2013). Developing generic tools for characterizing agricultural systems for climate and global change studies. Retri eved from

https://ccafs.cgiar.org/publications/devel oping-generic-tools-characterizingagricultural-systems-climate-and-globalchange. May 202016.

Samdup, T., Udo, H. M. J., Eilers, C. H. A. M., Ibrahim, M. N. M. \& Zijpp, A. J. Van Der. (2010). Crossbreeding and intensi fi cation of smallholder crop - cattle farming systems in Bhutan. Livestock Science, 132(1), 126-134.

Shiferaw, B., Kassie, M., Jaleta, M. \& Yirga, C. (2014). Adoption of improved wheat varieties and impacts on household food security in Ethiopia. Food Policy, 44, 272-284.

Silvia, S., Sabine, D., Patti, K., Wiebke, F., Maren, R., Ianetta, M., ... Cristina, R. M. (2015). Households and food security: lessons from food secure households in East Africa. Agriculture and Food Security, 4(23), 1-15.
Smale, M. \& Olwande, J. (2014). Demand for maize hybrids and hybrid change on smallholder farms in Kenya. Agricultural economics, 45, 409-420.

Stewart, R., Rebelo, N. \& Silva, D. (2016). Effects of training, innovation and new technology on African smallholder farmers' economic outcomes and food security. Systematic Review Summary 6, (July 2016).

Teklewold, H., Kassie, M. \& Shiferaw, B. (2013). Adoption of multiple sustainable agricultural practices in rural Ethiopia. Journal of Agricultural Economics 64(3), 597623.

Tiffen, M. (2006). Impacts on the evolution of "mixed farming" systems in sub Saharan Africa. Retrieved from,agris.fao.org/agrissearch/search.do?record. On June 2nd, 2016.

Trivedi, P. K. \& Zimmer, D.M., (2005). Copula modelling: an introduction for practitioners. Foundations and Trends in Econometrics, 1(1), 1-111.

Tscharntke, T., Clough, Y., Wanger, T. C., Jackson, L., Motzke, I., Perfecto, I., ... \& Whitbread, A. (2012). Global food security, biodiversity conservation and the future of agricultural intensification. Biological conservation, 151(1), 53-59.

Ulrich, A., Ifejika, C., Roden, P., Kiteme, B., Wiesmann, U. \& Nüsser, M. (2012). Smallscale farming in semi-arid areas: Livelihood dynamics between 1997 and 2010 in Laikipia , Kenya. Journal of Rural Studies, 28(3), 241-251.

United Nation. (2014). Concise report on the world population situation in 2014. Retrieved from http://www.un.org/en/development/de sa/population/publications/pdf/trends/ Concise Report on the World Population Situation 2014/en.pdf. On February 10 $0^{\text {th }}$, 2017.

Vermeulen, S. J., Aggarwal, P. K., Ainslie, A., Angelone, C., Campbell, B. M., Challinor, A. J., ... Wollenberg, E. (2012). Options for support to agriculture and food security under climate change. Environmental Science and Policy, 15(1), 136-144.

Wang'ombe, J. G. \& Dijk, M. P. Van. (2013). Low potato yields in Kenya: do conventional input innovations account for the yields disparity? Agriculture \& Food Security, 2(14): 
$1-11$.

WFP. (2008). Food consumption analysis: Calculation and use of the food consumption score in food security analysis. Retrieved from, https://www.wfp.org/content/technicalguidance-sheet-food-consumptionanalysis-calculation-and-use-foodconsumption-score-food. On January 17th, 2017.

Wooldridge, J. M. (2013). Introductory Econometrics: A Modern Approach (Fifth Edit). Boulevard Mason, USA: SouthWestern Cengage Learning.

Wodajo, W. A. (2017). Determinants of rural female-headed households ' food security in Ambo District, West Shewa Zone, Oromia Regional State, Ethiopia. Journal of Science and Sustainable Development, 5(1), $72-$ 87.

World Bank. (2016). Development goals in an era of demographic change. Washington, DC: The World Bank.
Xu, X., Wong, S.C. \& Choi, K, (2014). A two-stage bivariate logistic-Tobit model for the safety analysis of signalized intersections. Analytic Methods in Accident Research, 3, 1-10.

Yahaya, I., Pokharel, K. P., Alidu, A. \& Yamoah, F. A. (2017). Sustainable agricultural intensification practices and rural food security: the case of North Western Ghana. British Food Journal. Retrieve from www.https://doi.org/10.1108/BFJ-012017-0021. On 05 January 2018, At: 05:07.

Yitayih, M., Girma, A. \& Puskur, R. (2016). Determinants of success and intensity of livestock feed technologies use in Ethiopia : Evidence from a positive deviance perspective. Technological Forecasting and Social Change,115. 1-11.

Zakari, S., Ying, L. \& Song, B. (2014). Factors Influencing Household Food Security in West Africa: The Case of Southern Niger. Sustainability, 6(3), 1191-1202. 